
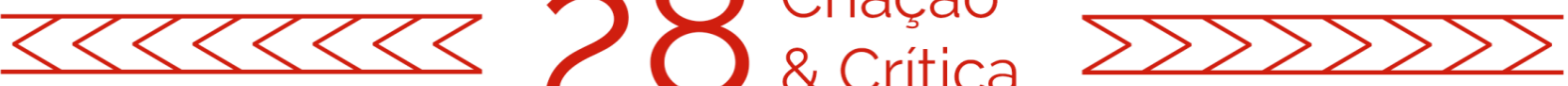

\title{
ENCONTROS, IMAGENS E CRUZAMENTOS NO ÁLBUM CLUBE DA ESQUINA (1972)
}

Rafael Julião ${ }^{1}$

Resumo: Entre os anos 1960 e 1970, o encontro de Milton Nascimento com compositores de Belo Horizonte deu início a um circuito de criação coletiva de férteis consequências para a história da canção popular no Brasil. O movimento ficou conhecido como Clube da Esquina, bem como o disco que o tornou célebre. O objetivo deste artigo é analisar o álbum Clube da Esquina (1972), enquanto objeto estético íntegro, produto de uma elaboração coletiva, procedendo à apreciação das canções, com especial atenção às letras, mas também à narrativa que formam quando tomadas em conjunto.

PALAVRAS-CHAVE: Milton Nascimento; Clube da Esquina; canção popular.

\section{MEETINGS, IMAGES AND CROSSINGS IN THE ALBUM CLUBE OF ESQUINA (1972)}

ABSTRACT: Between the 1960s and 1970s, Milton Nascimento's meeting with composers from Belo Horizonte started a circuit of collective creation, with fertile consequences for the history of popular songs in Brazil. The movement became known as Clube da Esquina, as well as the album that made it famous. The purpose of this article is to analyze the album Clube da Esquina (1972), as an integral aesthetic object, product of a collective elaboration, proceeding to the appreciation of songs, with special attention to the lyrics, but also to the narrative they form when taken together. KEY-WORDS: Milton Nascimento; Clube da Esquina; canção popular.

\section{O clube da esquina}

A esquina ficava em Belo Horizonte, entre as ruas Divinópolis e Paraisópolis, no bairro de Santa Tereza, e era lá em que jovens, como Lô Borges, reuniam-se para conversar, tocar violão, cantar e trocar experiências. O clube, na verdade, não era um espaço privado nem uma instituição formalmente; existia apenas na gíria de seus frequentadores da virada dos anos 1960 para os 1970, que se referiam ao ponto de encontro como "o clube da esquina".

A história do movimento, porém, começou antes, perto dali, em outro ponto da cidade. Em 1963, o jovem Milton Nascimento, nascido no Rio de Janeiro, mas criado no sul de Minas Gerais, em Três Pontas, mudou-se para o edifício Levy em Belo Horizonte, onde morava a família Borges (em especial, o irmão mais velho Márcio, e o mais novo, Lô) e também o então adolescente Beto Guedes. Márcio e Milton, de idades mais próximas, tornaram-se amigos e parceiros de experiências estéticas formativas, com ênfase especial para o cinema. Certo dia de 1964, a dupla de amigos assistiu a Jules et

\footnotetext{
${ }^{1}$ Doutor em Literatura Brasileira pela Universidade Federal do Rio de Janeiro.
} 

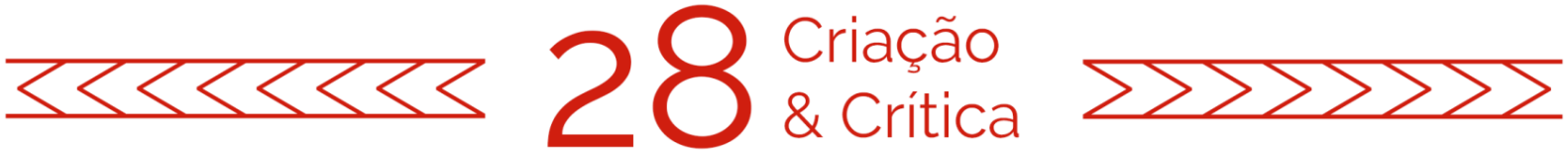

$\mathrm{Jim}^{2}$, de François Truffaut, e, impactados pela obra, começaram a compor canções. Tempos depois, Milton Nascimento conheceu, ainda em $\mathrm{BH}$, outro futuro parceiro, de nome Fernando Brant, com quem fez "Travessia".

Nessa época, Milton Nascimento já havia começado sua vida musical, na esteira das transformações acontecidas desde o advento da bossa nova no final dos anos 1950, mas também já se interessava pelo fenômeno dos Beatles. Ainda em 1964, Milton sugeriu que Márcio levasse seus irmãos mais novos, Yé e Lô, para assistirem ao filme $A$ Hard Day's Night, de Richard Lester, evento seminal para que os dois jovens, junto de Beto Guedes e outro colega, formassem o grupo The Beavers, cover da banda inglesa. Em 1966, Milton teria demonstrado entusiasmo também com o álbum dos Beatles Revolver, e decidiu comprá-lo para presentear os "meninos".

Essa sequência, relatada por Márcio Borges no livro Os sonhos não envelhecem - histórias do Clube da Esquina (1996) fornecem alguns indicativos de como se iniciou o processo de formação artística e da posterior profissionalização de Milton Nascimento, e também o enredo que o levará a, no início dos anos 1970, propor um disco com Lô Borges. A narrativa contribui também para recompor o contexto do Brasil daquele momento, tensionando entre o projeto de país que se desenhava na virada para os anos 1960 e a frustração política com a ditadura civil-militar que viria pouco depois.

Lembremos que, nos anos 1950, o otimismo do pós-guerra e uma nova onda de modernidade começavam a conferir à juventude grande centralidade. De um lado, chegavam ao país as modas jovens vindas dos EUA, como o rock'n'roll. De outro, a revolução empreendida pela bossa nova com a gravação de "Chega de saudade" em 1958 (e do disco homônimo, no ano seguinte), trouxe um processo de modernização da canção popular no Brasil, que tinha seu correspondente político no desenvolvimentismo do também mineiro Juscelino Kubitschek e na arquitetura moderna que inaugurou seu monumento no Planalto Central do país em 1960, a cidade de Brasília.

A televisão também se consolidava como veículo de comunicação de massas e, na esteira do rádio, oferecia diversos programas musicais, desde $O$ fino da bossa de Elis Regina e Jair Rodrigues ao Jovem Guarda do rei Roberto Carlos. Simultaneamente, começavam a proliferar os festivais da canção, especialmente a partir de 1965, transmitidos pelas principais emissoras, a TV Excelsior, TV Record e TV Rio (futura TV Globo).

Milton Nascimento insere-se nesse contexto em 1965, quando interpretou uma canção de Baden Powell no I Festival da Canção da TV Excelsior. No ano seguinte, a estrela televisiva Elis Regina fez seu clássico álbum Elis, em que a artista parece prenunciar, como propõe Hugo Sukman (2011), o cânone de sua geração. Nesse disco, além de Pixinguinha e da dupla Vinicius e Tom, há composições de Chico Buarque, Torquato Neto, Gilberto Gil, Caetano Veloso e Edu Lobo. A última faixa, a "Canção do

\footnotetext{
${ }^{2}$ Na versão brasileira, Uma mulher para dois (1962).
} 

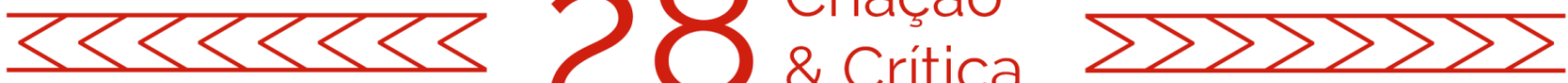

sal”, de Milton Nascimento, é uma canção que, como convinha ao momento, combinava apuro musical e sensibilidade social ("trabalho o dia inteiro pra vida de gente levar"). ${ }^{3}$

O momento decisivo, porém, de entrada de Milton na cena da canção popular brasileira é sua interpretação de "Travessia", parceria sua com Fernando Brant, no Festival Internacional da Canção, na TV Globo, quando ganhou como melhor intérprete, mas perdeu o prêmio principal para "Margarida" de Gutemberg Guarabira4. Na esteira desse evento, o artista lançou, ainda em 1967, o disco Travessia, que além da faixa homônima contava com canções como "Canção do sal", "Três pontas", "Morro velho" e "Outubro".

Mais três discos se seguiram a esse, precedendo o Clube da Esquina. Courage (1969), claramente voltado para o público estadunidense, trazia versões de várias canções do disco anterior, como de "Travessia" ("Bridges") e "Outubro" ("October"), e umas poucas novidades, como a faixa título "Courage" e, especialmente, "Vera Cruz". No mesmo ano, o artista lançou Milton Nascimento, no qual se destacam canções como "Sentinela", "Beco do Mota" e "Pai grande". Encerra a primeira fase de sua discografia o álbum Milton de 1970, que traz canções fundamentais, como "Para Lennon e McCartney" e "Clube da esquina no 1".

Podemos definir o Clube da esquina de 1972 como um disco duplo, conceitual e coletivo, proposto à gravadora Odeon por Milton Nascimento, que a essa altura se encaminhava para seus trinta anos. O artista, como se sabe, propôs dividir o álbum com Lô Borges, quando tinha apenas vinte anos. Seu ex-colega de Beavers, Beto Guedes, quase da mesma idade, também foi convidado a participar. As composições apresentam três letristas principais: Márcio Borges, seu primeiro parceiro, irmão mais velho de Lô; Fernando Brant, coautor de "Travessia"; e, por fim, Ronaldo Bastos, fluminense de Niterói, que conheceu Milton já no Rio de Janeiro.

Convém aqui, é claro, pensar sobre a redundância de dizer que Clube da esquina é um disco coletivo, como se algum disco não o fosse. Todo disco, evidentemente, é uma produção que envolve várias pessoas além do cancionista, entre músicos, compositores, produtores e profissionais de estúdio. À parte, é claro, o fato de que mesmo o artista solitário carrega em sua voz uma série de outras que a formam.

Assim, cada disco que ouvimos é atravessado por um sem fim de vozes, que dialogam entre si, conjugam-se em um movimento contínuo e contíguo de produção de sentidos. Deste mesmo modo, vale afirmar a importância de pensar a canção popular como objeto híbrido e complexo, cuja intepretação depende de um esforço analítico que conjugue os vários elementos que participam de seu sentido. Como nos ensina a semiótica de Luiz Tatit, é preciso perceber como letra, melodia e canto se entrelaçam e se potencializam mutuamente. Assim, é necessário estar atento aos elementos literários e musicais, tanto

\footnotetext{
${ }^{3}$ Todas as letras citadas neste trabalho foram consultadas no site oficial de Milton Nascimento, disponível em <http://www.miltonnascimento.com.br/letras.php>. Último acesso em 24 jul. 2020.

${ }^{4}$ Curioso pensar que isso ocorreu no mesmo ano que serve de marco para o tropicalismo musical, surgido em outro Festival da Canção, o da TV Record. Esse desencontro de canais ajuda a explicar a ausência de Milton Nascimento nesse episódio decisivo da canção popular.
} 

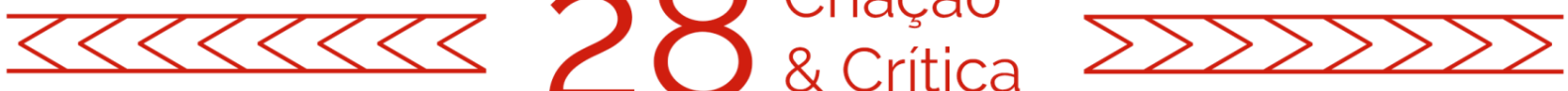

quanto à materialidade corpórea da voz e seus componentes de timbre, tom, volume e dicção. Isso sem contar uma série de elementos exteriores à canção, como seu próprio percurso histórico e suas variadas formas de apresentação, que vão adicionando mais camadas à sua expressão e, consequentemente, à sua apreciação analítica. ${ }^{5}$

Ainda assim, é preciso compreender que atribuir o rótulo de "disco coletivo" a Clube da esquina pode ser relevante. Em primeiro plano, sublinha-se que o disco é fruto de uma parceria entre Milton Nascimento e Lô Borges. Em seguida, notabiliza-se a participação de outros artistas, como Beto Guedes e Alaíde Costa. Enfatiza-se também a importância dos compositores de letras, tantas vezes minimizados diante da força do artista que visibiliza as canções. Assim, a tríade de letristas do clube - Márcio Borges, Fernando Brant e Ronaldo Bastos - ganha também uma nova dimensão. Por fim, os próprios músicos envolvidos, como Wagner Tiso, Eumir Deodato, Paulo Moura, Toninho Horta, Tavito, Nelson Angelo e Robertinho Silva também têm seu trabalho iluminado. Pode-se destacar inclusive o projeto gráfico do disco, no que se inclui a célebre capa com a imagem de dois meninos, um branco e um negro, tomada pelo fotógrafo Cafi, quem completa o conjunto de criadores e interfere no produto final, bem como na audição de cada canção.

O caráter coletivo do disco Clube da esquina é indicado pelo próprio título, que projeta uma referência geográfica e a própria ideia do encontro, quando a esquina indicaria o cruzamento de caminhos e de pessoas. Também é observado um referente externo, que é a história do movimento do "clube da esquina", amplamente narrada em entrevistas e documentários e, sobretudo, nas memórias de Márcio Borges no já referido Os sonhos não envelhecem. Uma extensa teia de significados vai se formando, o que contribui não apenas para o caráter prosaico gerado pelos encontros, mas para o próprio processo de auratização do grupo, cujo percurso se inicia no Edifício Levy com o filme Jules et Jim e segue pelos Festivais da Canção, pela canção "Travessia", por Guimarães Rosa, por Beatles, pela atmosfera mítica dos anos 1960 e 1970 e pela esdrúxula contemporaneidade entre a ditadura civil-militar brasileira e a informação libertária da contracultura internacional.

A afirmação de que se trata de um álbum conceitual também revela, para além de um vínculo com outras produções internacionais, a intencionalidade de cada elemento da obra, desde a escolha das canções, à sua sequência e distribuição, combinando músicas, letras e interpretações vocais, produzindo uma narrativa íntegra, cujos elementos centrais tratam dos sonhos, do compromisso com a liberdade e com a mobilidade, da tensão entre a solaridade e a escuridão, o presente e o passado, a vivência e a memória, além de sugerir projeções estéticas que revelam influências artísticas da literatura, do cinema, da canção e das artes plásticas.

Há nesse disco, ademais, a afirmação de identidades conjugadas, sendo identificados traços identitários de Minas Gerais, do Brasil, da América Latina, do Ocidente, e também da negritude, os quais vão sendo evocados em evidente tentativa de

\footnotetext{
${ }^{5}$ Para saber mais sobre a discussão proposta pelo autor, ver: TATIT, Luiz. A canção - eficácia e encanto. São Paulo: Atual, 1986.
} 

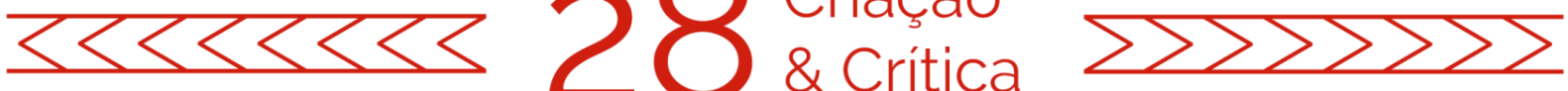

localizar e redimensionar o lugar de onde saem as expressões musicais e as vozes que por ele se propagam. ${ }^{6}$

Cabe evidenciar, do mesmo modo, a organização dos dois discos, divididos cada qual em dois lados, de modo a tentar compreender como essa distribuição funciona no conjunto poético-narrativo da obra. Para melhor nos situarmos, fique registrado: o primeiro disco conta com as canções "Tudo que você podia ser", "Cais", "O trem azul", "Saídas e bandeiras № 1", "Nuvem cigana" e "Cravo e canela" (no lado A) e com "Dos Cruces", "Um Girassol da Cor do Seu Cabelo", "San Vicente", "Estrelas" e "Clube da esquina nํㅡ" (no lado B); o segundo, "Paisagem da janela", "Me deixa em paz", "Os povos", "Saídas e bandeiras nํㄹ" e "Um gosto de sol" (no lado C) e, finalmente, "Pelo amor de Deus", "Lilia", "Trem de doido", "Nada será como antes" e "Aos que vão nascer" (no lado D).

Além da ordenação, devemos pensar também as canções entre seus intérpretes e seus compositores. Assim, em primeiro lugar, vale sinalizar que Milton Nascimento, Lô Borges e, eventualmente Beto Guedes, alternam-se ou combinam-se na defesa das canções (além da participação icônica de Alaíde Costa em "Me deixa em paz" de Monsueto Menezes e Ayrton Amorim). De outro lado, as composições giram em torno especialmente dos três letristas, Márcio Borges, Fernando Brant e Ronaldo Bastos, com Milton Nascimento ou Lô Borges. Nesse conjunto, apesar de particularidades estéticas de cada letrista e de cada músico, e também da importância da interpretação na construção dos sentidos, parece válido afirmar como as canções conseguem, em conjunto, atingir grande unidade, como se todos compartilhassem seus mecanismos e temáticas entre si, o que ressalta a relevância do caráter coletivo que esta análise procura sublinhar.

\section{Estradas e esquinas}

Para além da esquina, outro signo importante que atravessa todo o disco Clube da Esquina é a estrada. Não por acaso, a canção que abre o álbum é "Tudo que você queria ser", de Lô Borges e Márcio Borges, interpretada por Milton Nascimento. A estrofe inicial já afirma: "Com sol e chuva você sonhava/ que ia ser melhor depois/ você queria ser o grande herói das estradas/tudo que você queria ser". Desse modo, registra-se aqui o prenúncio de alguns elementos recorrentes da paisagem, visual e sonora, da obra: os elementos naturais basilares, os contrastes, o sonho, a busca da essência individual e, é claro, as estradas.

A referência ao cinema, constante nas composições de Márcio Borges, aparece aqui no intertexto com Viva Zapata!, filme de 1952, dirigido por Elia Kazan e protagonizado por Marlon Brando, que conta a história de um dos líderes da revolução mexicana de 1911 e, portanto, um dos responsáveis por derrubar o regime autoritário de Porfírio Diaz no país. A alusão aparece na segunda estrofe, que desfaz a projeção inicial: "Sei um segredo/ Você tem medo/ Não fala mais na bota e no anel de Zapata/ Tudo que

\footnotetext{
${ }^{6}$ Nesse sentido, é possível identificar no disco uma atitude, estética, filosófica e existencial, que bem podemos entender no âmbito das discussões pós e decoloniais.
} 

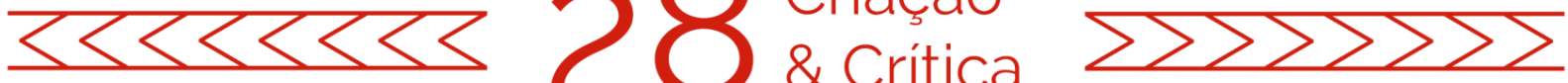

você devia ser, sem medo". Evidentemente, essas palavras cantadas em 1972, em um momento acirrado da ditadura civil-militar no próprio país, acabam por reforçar o contorno sugestivamente político de uma frustração, isto é, de uma revolução que não aconteceu. ${ }^{7}$

No entanto, para além da alusão ao filme, é possível identificar no disco (e na canção) o aproveitamento da estrada como signo da mobilidade, ao qual se somam os meios de transporte que aparecem ao longo do álbum, como o trem e o saveiro. A combinação entre natureza, estrada e liberdade apresenta-se como forma consagrada pela contracultura, desde o movimento beatnik dos anos 1950 (o livro On the road, de Jack Kerouac, de 1957, é exemplo emblemático) até movimento hippie (e seu lema de drop out, isto é, "cair fora" do sistema). Assinale-se ainda que o verão que ficou conhecido como "summer of love" aconteceu em 1967, e o apoteótico Festival de Woodstock, em 1969.

O signo da estrada apresenta também uma coerência interna com o trabalho de Milton Nascimento, conduzindo, para além do universo contracultural dos anos 1960, ao ideário de Minas Gerais. Inevitável lembrar que foi com o refrão que diz "solto a voz nas estradas" que Milton se apresentou ao grande público em 1967. Apesar de ter como mote uma separação, "Travessia" também nos transporta para a pedregosa paisagem mineira e as pedras que perpassam a poesia de Cláudio Manuel da Costa e Carlos Drummond de Andrade. Outrossim, o desenho de estradas, veredas e travessias remete imediatamente ao universo de outro escritor conterrâneo, Guimarães Rosa, cuja obra máxima, Grande sertão: veredas, de 1956, termina na palavra "travessia", exatamente a mesma com a qual começa a consagração de Milton Nascimento e de Fernando Brant.

A estrofe seguinte, aliás, desfaz a morte anunciada no refrão, falando em "seguir a vida" e terminando com uma negação do sonho e um imperativo de vida: "já não sonho, hoje faço/ com meu braço o meu viver". A retomada do refrão após essa estrofe ganha, portanto, mais uma camada, em que o sonho se converte em vida, o destino é diminuído em relação ao caminho, e a tomada de rédeas do próprio destino se alinha ao imperativo da mobilidade, conectando também essa canção ao universo de "Tudo que você podia ser".

Ressalta-se também que o sonho (e sua projeção no mundo real) é outro dado fundamental do ideário jovem dos anos 1960, relacionado a seu desejo de transformação individual e coletiva. Não por acaso, a canção que dá nome ao disco carrega consigo a icônica afirmação de que "sonhos não envelhecem".

A contracultura impactou profundamente também um conjunto de poetas da cena carioca dos anos 1970, que imprimiam seus livros em mimeógrafos e os distribuíam de modo artesanal. O fenômeno, como se sabe, ficou conhecido como "poesia marginal", não só porque representava uma produção à margem do circuito literário canônico, como também propunha uma poesia que seguia princípios estéticos e filosóficos outros, resultando em poemas marcados pelo despojamento, pelo cotidiano, pela irreverência e pela coloquialidade. Na mesma esteira, essa poética materializava uma espécie de ética

\footnotetext{
7 Vale observar que Porfírio Diaz é também o nome do personagem autoritário interpretado por Paulo Autran na alegoria realizada por Glauber Rocha em Terra em transe de 1967, outra obra icônica da frustração com o destino político do país no pós-golpe.
} 

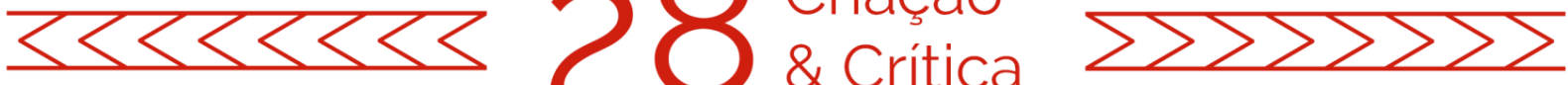

do desbunde que marcou aquele período, tematizando a liberdade, o movimento, a viagem, a sexualidade, as drogas, a negação do establishment, enfim, uma postura marginal em relação aos valores estabelecidos, que também aparece influenciada (e atravessada) por elementos da cultura de massas do período, do cinema, tanto europeu como hollywoodiano, como da canção popular internacional, de Bob Dylan a Beatles.

Por vezes, esses autores se organizavam em coletivos, como foi o caso da Nuvem Cigana, que reuniu poetas como Charles, Chacal, Bernardo Vilhena, Ronaldo Santos e, justamente, Ronaldo Bastos, que foi seu fundador em 1972, no mesmo ano do disco do qual também fez parte. Assim, um dos protagonistas do Clube da Esquina sinaliza uma interseção nítida entre o álbum e o universo da poesia marginal.

O título do coletivo dá nome também à quinta canção do lado $\mathrm{A}$ do disco. "Nuvem Cigana" é uma parceria de Ronaldo Bastos e Lô Borges, mas é interpretada por Milton Nascimento. Para além da referência óbvia à mobilidade que transpassa os dois significantes - "nuvem" e "cigana" - e também da ideia coletiva que subjaz à combinação, a canção retoma a idealização da estrada: "Se você quiser eu danço com você no pó da estrada/ Pó, poeira, ventania/ Se você soltar o pé na estrada, pó, poeira/ Eu danço com você o que você dançar" e, mais tarde, "Se você quiser eu danço com você/ Meu nome é nuvem, pó, poeira, movimento/ O meu nome é nuvem/ Ventania, flor de vento".

Comprometida com a ideia de movimento e com a afirmação da vida em uma chave existencialista, a canção revela novamente os vínculos do Clube da Esquina com o imaginário da contracultura internacional. Isto se confirma no refrão, que repete o verso "se você deixar o coração bater sem medo", exaltando a postura de quem se deixa levar pelo que sente, ao mesmo passo que faz o coração bater o ritmo da dança, intimamente ligada à canção, corpo e voz. ${ }^{8}$

Também Ronaldo Bastos, desta vez com Milton Nascimento, é compositor da canção "Nada será como antes", que é a penúltima canção do segundo disco, e é interpretada por Milton Nascimento e Beto Guedes. Mais uma vez, o mote se repete: "Eu já estou com o pé nessa estrada/ qualquer dia a gente se vê/ sei que nada será como antes, amanhã". A afirmação que encerra a estrofe também merece nota, construindo-se como constatação evidente da transformação de tudo, mas também como imperativo ético da abertura a um estado de metamorfose permanente, de si e do mundo.

Os versos seguintes, "que notícias me dão dos amigos/ que notícias me dão de você", reforçam a constatação sobre as constantes mudanças, mas ganham novas camadas diante do referente externo: o acirramento da ditadura civil militar após o Al-5 de 1968 e o subsequente governo de Garrastazu Médici entre 1969 e 1974. Nesse cenário, notícias chegavam frequentemente sobre desaparecimento e o exílio de pessoas no Brasil.

\footnotetext{
${ }^{8}$ Segundo depoimento de Ronaldo Bastos: "É uma música que considero muito emblemática daquele período. Porque ela vinha de uma ideia que era muito cara para nós de tentar juntar o estético com o existencial. Era algo ao mesmo tempo poético, político e que trazia uma informação muito clara do que estávamos vivendo. Essa ideia de circular por onde era possível, levar uma vida estradeira, estar em movimento, que era uma oposição radical à ditadura. E tentar construir um tipo de mito em cima disso" (BASTOS apud COHN, 2007, p. 68).
} 

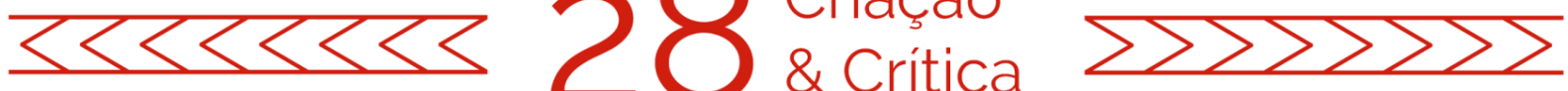

A bela imagem que encerra a canção - "resistindo na boca da noite um gosto de sol" - também se contamina desses sentidos, ao pensarmos na já referida contemporaneidade entre o caráter solar, estradeiro e libertário da juventude da virada dos anos 1960 para os anos 1970, e a sombria ditadura civil-militar que se fazia cada vez mais brutal e opressiva. Aliás, a mudança que se anuncia ao longo de toda a letra funciona também como esperança e ameaça - "sei que nada será como está/ amanhã ou depois de amanhã" -, contribuindo também para a resistência desse "gosto de sol em meio à noite".

"Clube da esquina no 2", de Milton Nascimento e dos irmãos Borges, é a canção que encerra o primeiro disco do Clube da esquina. A letra começa com a conjunção "porque", trazendo à luz a oração adverbial causal "porque se chamava moço/ também se chamava estrada/ viagem de ventania", o que tem como consequência os versos seguintes: "nem lembra se olhou pra trás ao primeiro passo, aço, aço, aço...". Assim, a ênfase recai sobre o núcleo temático que atravessa o disco, na relação entre mocidade e estrada - viagem e travessia - tão cara aos já referidos movimentos libertários da virada dos anos 1960 para 1970, e seu compromisso com o tempo presente (daí o sujeito que não se detém no passado, "nem lembra de olhar para trás").

Vale também perceber o efeito fonético dos versos que encerram as estrofes; no caso da primeira, o canto e a letra estabelecem um eco, de modo que a palavra "passo" vai se transformando em "aço, aço, aço". Metonimicamente, o aço remete aos grilhões, às algemas, às grades, colocando-se na antípoda do movimento libertador da estrada. Essa prisão que é existencial, ganha outras camadas, evocando as correntes da escravidão, da colonização, da ditadura civil-militar, do establishment. O fato de ser a voz de Milton Nascimento que projeta a canção contribui também para esse acúmulo de sentidos.

A segunda estrofe, do mesmo modo, antecipa a oração causal em nova sentença, que diz: "porque se chamavam homens/ também se chamavam sonhos/ e sonhos não envelhecem" e apresenta como consequência: "em meio a tantos gases lacrimogênios/ ficam calmos, calmos, calmos". A oração de causa reverbera evidentemente a célebre frase de $A$ tempestade, de Shakespeare, onde se constata que os homens são feitos da mesma matéria de que se fazem os sonhos. Mais uma vez, a juventude aparece na contramão do envelhecimento, carregada existencialmente pelo imperativo do sonho, do desejo, da imaginação e da liberdade.

Os gases lacrimogênios apontam imediatamente para os ambientes das manifestações e para a repressão policial, que nos levam de novo ao contexto ditatorial brasileiro, mas também ao imaginário de rebeldia jovem que se tornou definitivo com o Maio de 1968 (e com todos os seus lemas, tais como "A imaginação está tomando o poder"). Veja-se que os sonhos, em relação contígua com os sonhadores, são o próprio sujeito da oração "em meio a tantos gases lacrimogênios/ ficam calmos", no anúncio convicto do triunfo do desejo contra a brutalidade. A repetição de "calmos", reforçada pelo abaixamento do volume de voz e da velocidade de emissão da palavra repetida, confirma 

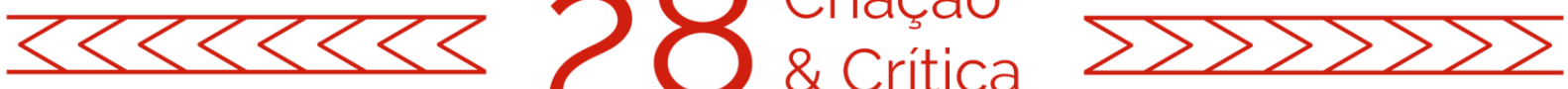

isomorficamente a afirmação. As duas primeiras estrofes encerram-se com um refrão de verso único, que modula o tempo da fala, enunciando: "e lá se vai mais um dia...".

As duas estrofes finais, intercaladas sempre pelo refrão que suspende o fluxo e nos chama atenção para o próprio tempo - para mais um dia que se vai -, voltam-se metalinguisticamente para a própria canção, por meio da palavra "compasso" ("e basta contar compasso/ e basta contar consigo/ que a chama não tem pavio/ de tudo se faz canção/ e o coração na curva de um rio, rio, rio..."). Aqui, o verso bem articulado na dicção e bem marcado na divisão nos chama atenção para o compasso da canção, para a relação entre o tempo, a vida e a música, bem como para a própria estrutura da palavra, que contém em si o passo individual (eco da primeira estrofe, "o primeiro passo") e o passo "com", coletivo como o próprio disco, como os movimentos de massa e juventude, as manifestações, as passeatas, as lutas políticas, os encontros afetivos, criativos e mesmo celebrativos.

Além do coletivo, a transformação individual é evocada por outra palavra que justapõe a preposição "com", desdobrando também o sentido do verbo "contar". Assim, "basta contar consigo" remete semanticamente a uma contagem interior e a uma postura independente, a uma transformação que é também individual, autocentrada ainda que coletiva, tal como defendem os movimentos contraculturais. Curioso também é que "consigo", além do caráter reflexivo, permite também a leitura do "com você" e, assim, o individual e o coletivo cruzam-se nos versos da canção. A metáfora que indica que "a chama não tem pavio", não só indica a força espontânea dessas manifestações, como também nos transporta para o universo de bombas, fogo e barricadas das manifestações que ambientam a composição.

O "rio" que aparece na estrofe final, retoma a ideia de fluxo, de movimento, de mobilidade que dá o tom à composição, o que se reforça com a própria repetição da palavra (tal como o faz o Guimarães Rosa de "A terceira margem do rio"). Sem contar a força da palavra "curva" 9 em um disco que tem a "esquina" no nome. É também o rio (e as esquinas) que conduzem à estrofe final em que as ruas ocupadas completam o conjunto de imagens de movimento e manifestação de uma juventude reivindicadora da liberdade: "e o rio de asfalto e gente/ entorna pelas ladeiras/ entope o meio fio" e, por fim, "esquina mais de um milhão/ quero ver então, a gente, gente, gente...". A repetição da palavra "gente", desta vez última, produz o próprio enchimento da rua, por meio da palavra e da canção, da própria incitação ao corpo nas ruas, da participação do fluxo geracional, da incontinência dos líquidos, da fluidez dos rios, que fazem seus desenhos e propõem travessias inesperadas, ritmos diversos, encontros e desencontros, passagens.

É interessante lembrar que a "Clube de esquina no 1" aparece ainda no álbum anterior, Milton (1970), que de algum modo serve de prelúdio à chegada do Clube da

\footnotetext{
${ }^{9}$ No mesmo verso, vale sinalizar a provável intertextualidade com o célebre Enterrem meu coração na curva do rio (1970) de Dee Brown, livro de grande sucesso no início dos anos 1970 sobre as lutas de resistência indígena nos EUA do século XIX.
} 

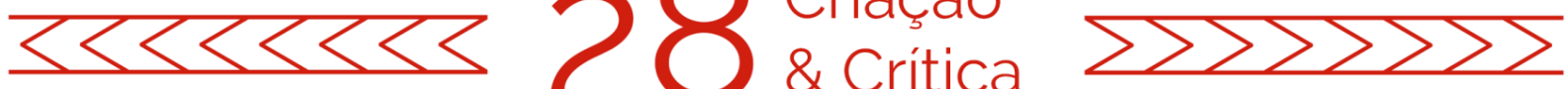

esquina. Na narrativa dos integrantes do disco (reiterada em diversas entrevistas e também no livro Os sonhos não envelhecem), a composição foi a parceria seminal do encontro entre Lô Borges, Milton Nascimento e Márcio Borges (estes dois últimos que já eram parceiros 1964). Como já se disse, a tal esquina de Belo Horizonte era um ponto de encontro da juventude do bairro, para conversas e violões na rua, e era especialmente frequentada por Lô Borges e Beto Guedes, os mais jovens do grupo. Sobretudo, a palavra "esquina" reforça a ideia de encontro - de curva do rio - que ganham suas dimensões humanas (no encontro de gerações e de pessoas que viabilizou o disco como obra coletiva), mas também estéticas (que se fez da junção da toada mineira, do jazz fusion, do pós-bossa nova, da música erudita e do neo-rock'n'roll inglês dos Beatles).

Nessa canção, não há o universo estritamente político das passeatas, mas um encontro noturno de pessoas à noite na rua, na tal esquina, vivendo suas fugas, dividindo suas solidões. Por outro lado, a segunda estrofe já prenuncia uma mirada maior, para além da própria manifestação política inerente à ocupação das ruas e da vivência da liberdade: "um grande país eu espero/ espero do fundo da noite chegar/ mas agora eu quero tomar suas mãos/ vou buscá-la onde for/ venha até a esquina/ você não conhece o futuro/ que tenho nas mãos". Aqui, o sujeito e o país projetam-se em uma mesma esperança, e a noite lírica toma a dimensão do tempo sombrio em que vivia o país na virada das décadas. O amor - marcado pelas mãos dadas - aparece aqui na voz do cantador como promessa de redenção.

É importante também pensar que a noite lírica, a romântica noite de luz, solidão, canto e fuga, termina sua última estrofe dizendo: "do fundo da noite partiu minha voz/ já é hora do corpo vencer a manhã/ outro dia já vem/ e a vida se cansa na esquina/ fugindo, fugindo, pra outro lugar". Assim, o vate romântico, cuja voz atravessa a noite, anunciando o outro dia, completa a atmosfera escapista encarnada na esquina noturna de Minas Gerais. Curioso pensar que, se aí era feito o anúncio do dia que já vem, "O Clube da esquina no 2" fala não mais deste, mas do dia que vai ("lá se vai mais um dia..."), da vida vivida, não da esquina parada de onde se projeta a voz do vate, mas da esquina em movimento onde caminham as multidões que querem construir o país, cheias de futuro nas mãos.

\section{Azul, girassol, peras e canela}

Além de trazer novidades musicais, os anos 1960 também foram um importante ponto de virada na composição de letras de canção. A influência contundente dos meios de comunicação modernos, do cinema ao jornalismo, foram acompanhando a gradativa aceleração da vida moderna, levando a novas formas de captação das cenas cotidianas. Isso tudo, é claro, resulta de um aprofundamento das questões já amplamente discutidas desde o primeiro Modernismo de 1922. Desse modo, a influência das vanguardas europeias (suas obras e manifestos) e o desenvolvimento da fotografia e do cinema, trouxeram outras possibilidades também para a literatura e para a canção, sugerindo outras luzes, cortes, enquadramentos e montagens. 

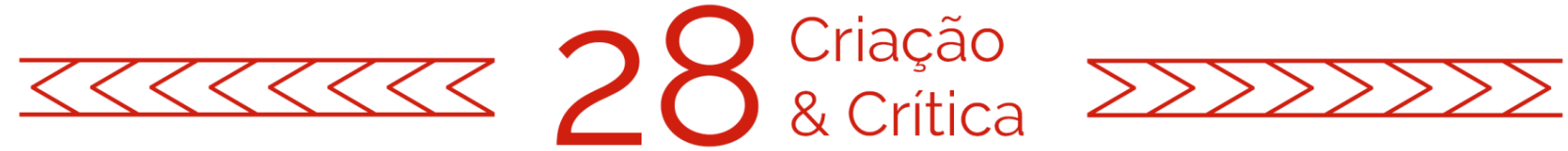

Vale lembrar que, além dos influxos do primeiro Modernismo, as poéticas dos anos 1960 aparecem também atravessadas por uma série de outros elementos, como o jazz, o blues e rock'n'roll (e o neo-rock'n'roll inglês), o desenvolvimento da arquitetura moderna e de suas premissas (especialmente nos anos 1940 e 1950), o concretismo e a poesia concreta, os debates em torno da propaganda e da linguagem publicitária, os novos grupos de teatro experimental e político, o cinema hollywoodiano e o cinema europeu, com destaque para o neorrealismo italiano e a Nouvelle Vague francesa, além do próprio Cinema Novo brasileiro.

Os três letristas principais do Clube da Esquina mostram-se diretamente envolvidos com essas novidades estéticas e, evidentemente, são fecundados por elas. Márcio Borges relata em seu livro que foi crítico de cinema na juventude e que projetava uma carreira de cineasta, na qual a canção amparava-se na imagem, enquanto tema de filme. Lembremos que Jules et Jim, de Truffaut marca, em sua narrativa, o momento de fecundação da parceria entre ele e Milton Nascimento. Fernando Brant também experienciou o mesmo contexto de efervescência cultural de Belo Horizonte no início dos anos 1960, além de deter vasto conhecimento literário, envolvendo-se também com o direito e o jornalismo. Ronaldo Bastos foi um dos fundadores de um coletivo da Nuvem Cigana, cujos participantes, como se disse há pouco, frequentemente reportam a importância do cinema europeu e da canção popular ao mencionar suas formações e a estética da poesia marginal.

Sendo assim, vamos agora observar alguns elementos interessantes na potência visual das composições do disco Clube da esquina, dando ênfase àquelas em que o caráter imagético, o enquadramento e a paleta de cores nos ajudam a compreender melhor o disco de modo amplo. Nesse sentido, podemos pensar na imagem do trem azul, no girassol amarelo, nas peras sobre a mesa e na morena cor de canela que enchem de cores o Clube da esquina, para além do branco e do negro. Vale reiterar também que não é apenas a letra que se torna responsável pela pintura da canção - as vocalizações e os instrumentos também imprimem cores e texturas.

"O trem azul" é a terceira faixa do disco (lado A), uma canção de Lô Borges em parceria com Ronaldo Bastos, e é interpretada por Lô Borges. Sabe-se que o trem é um meio de transporte moderno, que faz parte constante do imaginário mineiro, e não raro aparece na obra de Milton ("Três pontas", "Morro velho" e "Encontros e despedidas", além da célebre capa de Geraes, são alguns dos exemplos). A letra toda se compõe de duas estrofes, de versos construídos por estruturas sintáticas simples e paralelas, que se recombinam em operações minimalistas.

Na primeira estrofe, ainda sem o trem anunciado no título, a canção se abre com "Coisas que a gente se esquece de dizer/ Frases que o vento vem às vezes me lembrar/ Coisas que ficaram muito tempo por dizer/ Na canção do vento não se cansam de voar". A imagem do vento, outro signo de mobilidade, funciona na letra como um leva-e-traz de memórias. O paralelismo sintático dos três primeiros versos fica evidente, bem como as aliterações das fricativas $/ \mathrm{v} / \mathrm{e} / \mathrm{s} /$, que reforçam a evocação sonora do vento. A leve 

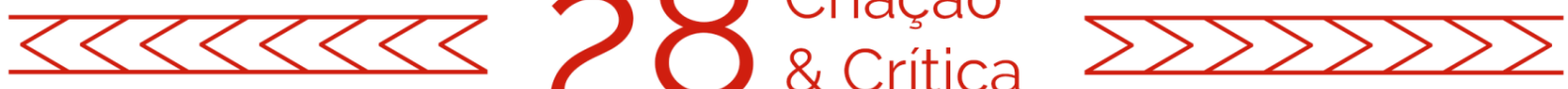

variação de "frases que o vento" para "na canção do vento" encaminha a metalinguagem, na qual um vento compositor vai articulando a lembrança e a palavra.

A segunda estrofe concentra-se em uma ideia base, na qual o sol, o trem e a pessoa que serve de interlocutora ("você") giram de modo minimalista, entre inversões e recombinações sintáticas. Cabe destacar o parentesco entre o "sol" e o "vento" na coesão interna da letra, bem como da memória que evoca a expressão "na cabeça". Assim, temos os versos "Você pega o trem azul/ O sol na cabeça/ O sol pega o trem azul/ Você na cabeça/ O sol na cabeça" para produzir a imagem do trem que, submetido ao vento, à sua cor azul, mas também à memória, é alvo dos efeitos de deformação da cena captada, à moda das vanguardas.

A permutação de sintagmas (ora é o "você", ora é "o sol" que pega o trem azul; ora é "o sol", ora é o "você" que está "na cabeça") vai formando quadros superpostos, de imagens geometrizáveis, tais como o sol, o trem e a própria cabeça, se tomada no sentido literal (o sol batendo na cabeça), embora essa imagem também se fissure conotativamente, propondo um sol que está na lembrança ou no pensamento. Por outro lado, a recombinação sintática que parte de uma cena plausível (alguém entrando em um trem azul) também pode levar a uma imagem insólita, na qual o "o sol pega o trem azul", o que desafia a imaginação da cena, a não ser que lembremos que o verbo "pegar" também é polissêmico, de modo que o verso tornar-se-ia compreensível se o sentido fosse o de "atingir, tocar". Nesse caso, o sol desdobra-se entre passageiro do trem e raio que o alcança. Nesse último sentido, é justamente o controle da luz solar que contribui para abrir o azul do trem (e também do céu), ativando nele os sentidos positivos da memória que refaz a cena.

Cabe ainda observar que a primeira estrofe é cantada com a voz solo de Lô Borges, que articula de modo preciso e mais lento os versos entre o ritmo bem marcado dos instrumentos, em especial da percussão, enfatizando esse movimento dispersivo da lembrança e conversando diretamente com a paisagem sonora sugerida pelo trem. $\mathrm{O}$ prolongamento da emissão da palavra "voar" reforça no significante seu significado, abrindo caminho para que a canção do vento traga a memória do trem. Na segunda estrofe, começa o coro do qual participa Beto Guedes e Toninho Horta, a melodia e o canto se enchem e se aceleram, e o tom sobe. Essa mudança sonora acompanha os processos de deformação da cena e contribui para a multiplicidade de efeitos visuais, que corre contígua à descrição dos movimentos da memória.

Outra letra de forte apelo visual é "Um girassol da cor do seu cabelo", segunda canção do lado B do disco, interpretada também por Lô Borges e fruto da parceria deste com seu irmão Márcio Borges. Mais uma vez, o vento e o sol são elementos estruturantes da composição, que capricha na harmonização entre o azul e o amarelo. A divisão das quatro estrofes iniciais em dois pares paralelos intercalados e novamente as recombinações sintáticas são responsáveis pelo desdobramento dos quadros e das cores.

A letra começa dizendo: "Vento solar e estrelas do mar/ a terra azul da cor de seu vestido/ vento solar e estrelas do mar/ você ainda quer morar comigo?". Note-se que a luz que ilumina a cena se impõe logo no primeiro sintagma ("vento solar"), coordenado a 

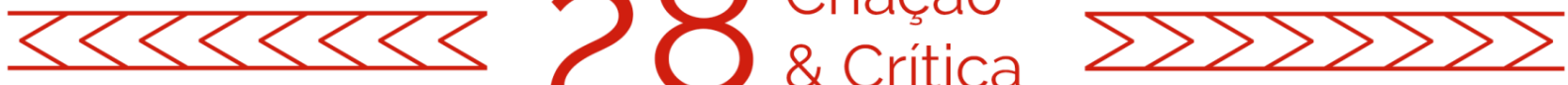

"estrelas do mar", tingindo de azuis o céu e o mar, e ainda evocando a imagem (amarela) desse interessante animal aquático, designado em seu parentesco tanto com o ar quanto com a água. O verso "você ainda quer morar comigo?" paira misterioso no cenário, de onde surge essa interlocutora.

A terceira estrofe, a esta paralela, anuncia "Sol, girassol, verde vento solar/ você ainda quer morar comigo/ vento solar e estrelas do mar/ um girassol da cor de seu cabelo". Já no primeiro verso, o sol ilumina a cena apresentada por coordenação sintática entre o "sol", o "girassol" e o agora "verde vento solar", iluminando as folhas verdes em movimento e estabelecendo uma continuidade entre os quadros coordenados. Agora, a imagem do sol projeta-se no girassol que lhe busca, em um eco a um só tempo sonoro e imagético.

O amarelo do girassol projeta-se agora na cor do cabelo (louro) da pessoa lembrada na primeira estrofe, em "você ainda quer morar comigo", no verso exatamente paralelo a este, que agora migra para a segunda posição dessa nova estrofe. Aliás, a proximidade da flor com o cabelo, ainda poderia nos reportar o uso do girassol como adereço na orelha, à moda flower power que dava tom ao movimento hippie daquele momento. Assim, é o próprio arranjo de cores da natureza que evoca a lembrança da pessoa amada.

As estrofes pares se abrem pelos versos "se eu cantar não chore não/ é só poesia" e "se eu morrer não chore não/ é só a lua", e intensificam a função apelativa da linguagem, buscando saber como ela está e se ela ainda se interessa pelo sujeito da canção. Voltando ao pacto de cores, a quarta estrofe segue o signo da lua, cambiando o cenário para a noite e dizendo: "é seu vestido cor de maravilha nua,/ ainda mora nesta mesma rua,/ como vai você?/ você vem, ou será tarde demais?". Note-se que o vestido azul que aparece na primeira estrofe é fundamental para entendermos como céu e vestido de um lado, sol, girassol e cabelo de outro, vão formando uma harmonia de cores. Outra imagem surreal, ou ao menos insólita, aparece no paradoxo de um vestido que tem cor de "maravilha nua", e que a nível sonoro ecoa a lua e também a rua, o endereço, o espaço que liga afetivamente essa relação que se projeta do passado ao momento presente.

O canto de Lô Borges começa novamente pausado, reforçando as coordenações sintáticas da composição. A voz doce sublinha o lirismo da cena. A subida do tom e a aceleração do canto subsequentes, por sua vez, reforçam o caráter apelativo dos versos, dessa interlocutora resgatada imageticamente e interpelada sobre um possível resgate do sentimento passado, vivido em um lugar determinado pela casa, o endereço, a rua. Uma intervenção instrumental após o verso "é tarde demais" dá ainda mais gravidade e dramaticidade a essa ausência. Na sequência, o instrumento sai de cena e volta o arranjo original, no qual o coro canta de forma leve e lírica o que seria a quinta estrofe, explorando apenas o jogo entre os versos: "O meu pensamento tem a cor de seu vestido/ ou um girassol que tem a cor de seu cabelo", de modo que a memória vai se tornando mais viva e reiterada, até que o volume vai baixando, até que se dissolva. Agora é o próprio pensamento que tem a cor do vestido (retomando o azul, a lua, a maravilha nua) e coordenando com conjunção alternativa o girassol (retomando o amarelo, o sol e o cabelo louro). A pessoa amada aqui apresenta-se à memória fragmentada, entre o azul e o 

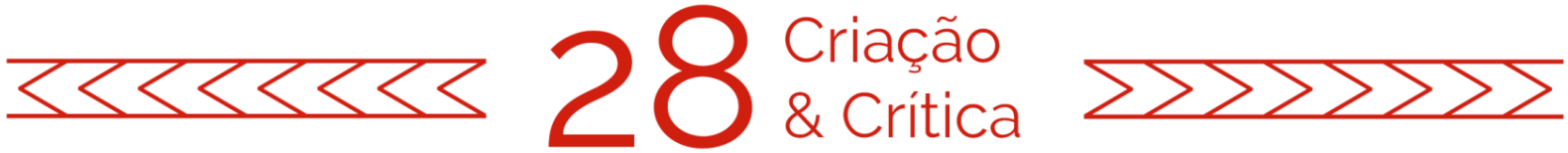

amarelo, o vestido e o cabelo. Essa alternância de orações é também a alternância das cores que, postas em movimento, vão se dividindo e se atravessando num arranjo cromático de grande potência expressiva.

Outra canção de impressionante composição imagética é "Um gosto de sol", de Ronaldo Bastos e Milton Nascimento, que utiliza fartamente de seus falsetes para reforçar o caráter memorialístico da canção. A letra forma uma espécie de natureza morta surrealista, com ecos do famoso poema de Ferreira Gullar de A luta corporal (2017, p. 58) sobre as peras que apodrecem no prato. O compositor, para tanto, faz uma sequência de símiles, formando imagens sobrepostas: "como uma pera se esquece/ dormindo numa fruteira", "como adormece o rio/ sonhando na carne da pera/ o sol na sombra se esquece/ dormindo numa cadeira". O mote da canção são as lembranças provocadas por "alguém que me viu de passagem/ numa cidade estrangeira/ e lembrou os sonhos que tinha/ e esqueci sobre a mesa" e depois "alguém sorriu de passagem/ numa cidade estrangeira/ lembrou o riso que eu tinha/ e esqueci entre os dentes". Notem-se aqui novamente os sonhos, o caráter difuso da memória, os paralelismos, os atravessamentos entre passado e presente, enfim, várias das linhas de força do disco.

Por fim, vale comentar a composição "Cravo e canela", outra parceria de Ronaldo Bastos com Milton Nascimento, que a interpreta junto de Lô Borges. Trata-se da sexta e última canção do Lado A do disco, e apresenta um interessante jogo sinestésico, envolvendo as cores e os aromas das especiarias que lhe dão título, que casam também com a paisagem sonora que nos reporta a um universo afro-brasileiro, para além da evidente referência ao clássico romance de Jorge Amado, Gabriela, cravo e canela (1958).

A letra também se apresenta por meio de coordenações sintáticas com a sequência interrogativa "Ế morena quem temperou?/ Cigana quem temperou?/ O cheiro do cravo/ É cigana quem temperou?/ Morena quem temperou?/ A cor de canela". São muitas coisas a notar. Em primeiro lugar, o intercâmbio entre "morena" e "cigana", em uma evocação que apresenta camadas identitárias que vão da raça ao gênero e ao modo de vida. Observe-se que retorna aqui o signo da "cigana" (que aparece em "Nuvem cigana" e abre o já referido universo nômade e místico retomado pelo imaginário dos anos 1960-70). O uso da interjeição "Ê" no vocativo também aponta para uma variação linguística marcada racialmente.

A ligação entre essa figura feminina, morena e cigana, e o universo culinário dos temperos e da cozinha mostra atravessamentos históricos, sociais e culturais. $O$ paralelismo entre o "cheiro do cravo" e "a cor de canela" contaminam-se mutuamente (ativa também a imaginação sensória da cor negra do cravo e do perfume específico da canela), e projeta-se na própria interlocutora de pele morena, tal qual a cor da especiaria. Aliás, o exercício de imaginar uma cozinha antiga de Minas Gerais também nos conduz, pelas panelas de barro e cerâmicas, à semelhante paleta de cores.

As outras estrofes que se alternam com esse refrão também apresentam estruturas simples e intercâmbios sintáticos: "A lua morena/ $A$ dança do vento/ O ventre da noite/ E o sol da manhã" e "A chuva cigana/ A dança dos rios/ O mel do cacau/ E o sol da manhã". Os adjetivos "morena" e "cigana", que no refrão têm força substantiva na 

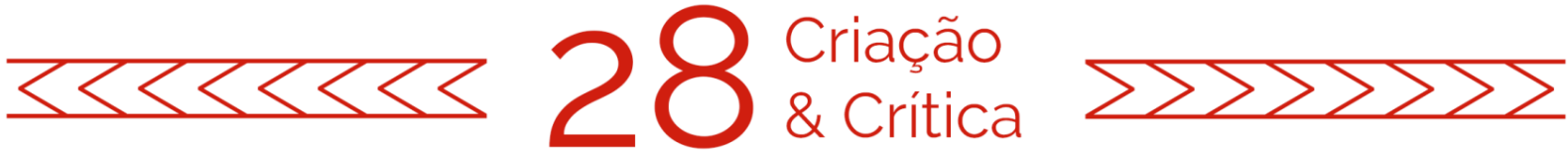

designação da protagonista da canção, passam agora a características da lua e da chuva. O verso "o mel do cacau" acaba por retomar potencialmente, por contiguidade, a dimensão visual e olfativa do cravo e da canela, além de evocar a llhéus da Costa do Cacau na Bahia dos anos 1920, que serve de cenário ao romance de Jorge Amado. Os elementos naturais aqui (a lua, o vento, a noite, sol, a chuva, a noite e a manhã) são temperados por personificações, que revelam não apenas a força anímica da natureza, mas também criam uma mútua interferência entre o humano e o natural, ambos atravessados por movimentos, cores e aromas.

A percussão da introdução quase sugere as palmas, combinadas com a melodia do assobio. Ao timbre e à dicção de Milton Nascimento, junta-se o coro, propositalmente feito de vozes não exatamente coincidentes, mas sublinhando sua combinação coletiva. Essas vozes, como temos argumentado, vão dando colorações e texturas, e atravessam profundamente esse universo racialmente marcado, desde o conteúdo da letra (o lugar da cozinha, a morena, a intertextualidade e o próprio trânsito do cravo e da canela no mundo Atlântico) até sua forma (a marcação das palmas, o canto coletivo, o timbre e a dicção de Milton Nascimento).

\section{A janela, os povos e o cais}

Se o primeiro dos dois discos de Clube da Esquina (1972) começa pelo signo da estrada e do movimento (que reverberam em "Nuvem cigana" e "Clube da esquina no 2"), o segundo começa em um ponto estático e determinado, de onde o sujeito mira o cenário e suas projeções. Trata-se de "Paisagem da janela", letra de Fernando Brant para a música de Lô Borges, interpretada por este último. Se, na primeira, evoca-se um herói revolucionário ("um herói das estradas"), na segunda, ilumina-se a imagem de um "cavaleiro marginal", "um cavaleiro negro que viveu mistérios", imbuído de uma força visionária.

Assim como "Clube da esquina no 1" ("janelas se abram ao negro do mundo lunar/ mas eu não me acho perdido/ do fundo da noite partiu minha voz"), "Paisagem da janela" também constrói essa imagem do vate, que da janela é capaz de ver muito mais do que simplesmente o cenário em sua frente. Mais do que isso, ele é capaz de revelar aos outros homens o que vê, mesmo que estes permaneçam incrédulos.

A construção da letra, menos romântica que cubista, vai apresentando aos poucos o sujeito que enuncia, começando por sua localização, "da janela lateral", que ecoa no "mensageiro natural" e, por fim, no "cavaleiro marginal", as três formulações encaixando-se no mesmo desenho melódico. A primeira estrofe começa desenhando a tal paisagem da janela, que é uma janela lateral, oblíqua, angulosa, vinculada ao quarto de dormir e, por extensão, de sonhar, de imaginar. De lá, afirma ver "uma igreja", "um sinal de glória", "um muro branco" e "um voo pássaro", "uma grade" e "um velho sinal", isto é, uma paisagem urbana, captada de modo fragmentário por meio de coordenações sintáticas, em torno de um cemitério, conforme vamos descobrir depois. 

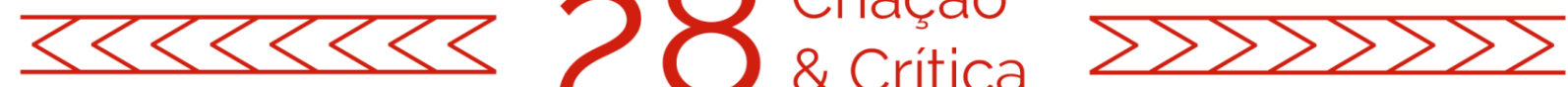

Note-se o refinamento construtivo de uma imagem como "vejo um voo pássaro", na qual "pássaro" ganha dimensão adjetiva, mas não se apresenta em forma de locução como seria esperado ("um voo de pássaro"). Com essa espécie de cubismo sintático, o compositor garante a métrica ("um-mu-ro-bran" e "um-vo-o-pá") e o paralelismo entre os adjuntos adnominais "branco" e "pássaro", além de manter a coincidência esdrúxula entre proparoxítonas no final dos versos (a palavra "glória" pronunciada de modo a criar o hiato). Sobretudo, conquista-se assim a imagem do voo que sobressai à do próprio pássaro, atravessando o resto da cena

Na sequência, o observador torna-se "mensageiro natural" (ou seja, dotado de uma força espontânea), que vai falar sobre "as cores mórbidas", sobre "os homens sórdidos", sobre "esse temporal", mas sem ser acreditado ("você não quis acreditar"). O vate, mensageiro natural que vê além dos demais, percebe a chegada de um cenário sombrio regido por homens sórdidos, contra os quais se coloca à parte, à margem. Mais uma vez, não seria impertinente lembrar dos homens violentos, conservadores, tecnocráticos e autoritários que encarnaram os inimigos da contracultura internacional e, mais especificamente, no caso brasileiro, participaram ativamente do período sombrio do regime militar que contextualiza o álbum.

Assim, na contramão, chegamos à terceira estrofe, quando o sujeito se apresenta apenas como "cavaleiro marginal" (tal como a poesia, também à margem), porém "lavado em ribeirão" (o herói marginal, ou o marginal herói no estandarte de Oiticica), a um só tempo maldito e purificado ("lavado em ribeirão"), e desenhado precisamente em um contexto espacial que une o ribeirão e a igreja na cena urbana, que bem podia nos trazer à mente as cidades pequenas de Minas Gerais. Além disso, esse "cavaleiro negro" (mais um traço de contraposição ao herói branco, hegemônico) se projeta numa dimensão sobre-humana, já que "viveu mistérios", é "senhor de casas e árvores" e parece ver de fora (de lado e de cima) "os homens e os seus velórios". A letra, por fim, faz seu movimento de retorno à janela lateral, retornando ao ponto de observação do sujeito e reafirmando a descrença de seu interlocutor.

A canção "Os povos" também evoca a imagem do cemitério e de uma cidade morta. A composição é uma parceria de Márcio Borges e Milton Nascimento, e é a terceira canção do segundo disco, pouco depois de "Paisagem da janela". A letra começa dizendo: "Na beira do mundo/ Portão de ferro, aldeia morta, multidão/ Meu povo, meu povo/ Não quis saber do que é novo, nunca mais" e, na mesma sequência, "Eh, minha cidade/ Aldeia morta, anel de ouro, meu amor/ $\mathrm{Na}$ beira da vida/ A gente torna a se encontrar só".

O caráter elíptico da letra nos leva a uma outra vez fragmentária visão de uma aldeia morta, à qual se vincula o povo do sujeito cancional. Esse espaço se opõe a uma cidade nova que se the sobrepõe. Sendo também a cidade do eu-lírico ("minha cidade"), cria-se uma fissura entre ele e o espaço, desdobrados entre o presente e o passado. Como seu povo rejeita a chegada desse novo, justificam-se também as contraposições 

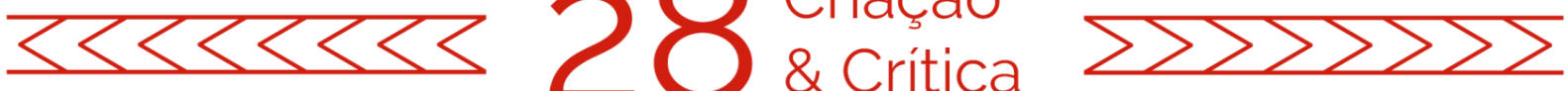

entre multidão e solidão, perfazendo um espaço "na beira da vida", na "beira do mundo", no qual um "a gente" aprende a "se encontrar só".

Milton Nascimento dá voz a essa canção, de modo que sua dicção e timbre acrescentam camadas a essa composição tão cheia de lacunas. Nesse sentido, é possível supor nessas cidades sobrepostas pelo tempo o próprio processo de formação do país, de seu arcabouço arcaico, colonial e escravocrata, e seu presente discurso modernizador, que, desde a primeira república (e enfaticamente no período ditatorial de Médici), exalta um progresso e uma modernização, em verdade excludentes, que buscam apagar as vozes dos povos formadores do país, mas não a herança perversa de seu sequestro, escravização e genocídio.

Esse reencontro de um povo, posto à margem, é traço fundamental da compreensão sobre a formação de uma cultura africano-diaspórica, espalhada pelo mundo Atlântico e base de construção das Américas. Justamente a canção, bem como outros elementos da cultura popular negra, vão se cristalizando como forças de resistência às violências de várias ordens que se impõem a esses povos, como bem assinalam os trabalhos de Stuart Hall e Paul Gilroy ${ }^{10}$, para ficarmos em dois exemplos icônicos.

Essa interpretação não se ancora apenas no título e nas pistas que a letra dá, e na própria vocalização de Milton Nascimento que oferece corpo e materialidade à dimensão racial dessa composição, mas se ampara também em outras canções emblemáticas da trajetória pregressa do artista, desde "Morro velho" do disco Travessia de 1967 a composições fundamentais de Milton Nascimento de 1969, aquele que traz justamente na capa uma paisagem reconhecidamente mineira, com um rosto enorme, de feições negras, desenhado em azul, ao fundo, mirando de cima a cidade. A imagem nos conduz à figura do próprio artista, mas aponta para o que seriam traços arquetípicos e simbólicos, preparando a discussão do álbum para o lugar do negro na construção daquele espaço, notoriamente de origem colonial.

Nesse sentido, destacam-se canções como "Sentinela" ("Longe, longe ouço essa voz/ que o tempo não vai levar" e "a morte inda não vai chegar/ se a gente na hora de unir/ os caminhos num só/ não fugir nem se desviar") e "Pai grande" ("Meu pai grande/ quisera eu ter sua raça pra contar/ a história dos guerreiros/ trazidos lá do longe/ trazidos lá do longe/ sem sua paz)". O cantador-contador, voz transtemporal, que corta os espaços e fixa no país sua presença ancestral é o grande tema desse disco, justificativa do rosto negro pairando sobre a cidade colonial.

Voltando a "Os povos" e, por conseguinte, ao disco Clube da Esquina, a canção segue na estrofe seguinte seu ritmo elíptico e fragmentário em que o sujeito afirma: "Casa iluminada/ Portão de ferro, cadeado coração/ E eu reconquistado/ Vou passeando, passeando e morrer". Vale notar aqui também a referência a um conhecido ponto de

\footnotetext{
10 Essas reflexões aparecem de modo bem desenvolvido em trabalhos como: GILROY, Paul. O Atlântico negro: modernidade e dupla consciência. São Paulo: Ed. 34; Rio de Janeiro: Universidade Candido Mendes, Centro de Estudos Afro-Asiáticos, 2001; e também HALL, Stuart. Da diáspora: identidades e mediações culturais. Belo Horizonte: Editora UFMG, 2013.
} 

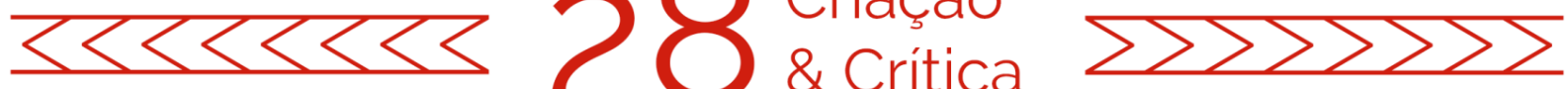

umbanda (ou ao menos, a uma de suas variantes), que diz "portão de ferro, cadeado de madeira/ é na porta do cemitério/ onde mora Exu Caveira".

Essa entidade representa, em cultos de ascendência afrobrasileira, o domínio das porteiras, dos cemitérios e das encruzilhadas. Na canção, essa referência vai aparecendo fragmentada, com pausas que levam a outros sentidos. Na primeira versão, "Portão de ferro, aldeia morta, multidão", o portão limita a cidade antiga, a aldeia morta. Na segunda, "Portão de ferro, cadeado, coração", a tranca se metaforiza em relação ao coração, isto é, ao domínio da própria essência, da própria liberdade, dos próprios sentidos, o que ilumina evidentemente o verso seguinte, em que o sujeito se reconquista e se coloca em movimento ("passeando, passeando").

A penúltima estrofe é formada por um terceto, que diz: "Ah, um dia, qualquer dia de calor/ É sempre mais um dia de lembrar/ A cordilheira dos sonhos que a noite apagou". Assim, outra vez aparecem aqui os sonhos apagados e a própria presença da cordilheira, de algum modo, nos transporta tanto para a pedregosa paisagem mineira quanto para uma visão da América Latina e as tensões que, entre as décadas de 1960 e 1970, foram duelando entre os movimentos revolucionários e a imposição dos regimes autoritários e reacionários (lembremos aqui da canção que abre o disco fala em Zapata). O imperativo da memória, que aparece em outras canções de Milton, como já se disse, de "Beco do Mota" a "Pai grande", é também um chamado histórico para os povos, especialmente aqueles que, marcados social, racial e geograficamente vão construindo as mesmas cidades às quais não têm direito.

A canção se encerra com a repetição reiterada dos versos "Meu povo, meu povo/ pela cidade a viver só", retomando a imagem de um povo, reunido pelo possessivo e dispersado pelo projeto de cidade (de país e de mundo) trazido pelas diversas fases da modernidade. De todo modo, a evocação do arquétipo de Exu-Caveira (aparentemente proposital) ressalta a presença da morte - de aldeia morta -, mas também do portal que conecta os mundos, ou melhor, da encruzilhada, com todas as suas possibilidades. $O$ senhor das encruzilhadas fecunda profundamente esse álbum que leva no título uma esquina.

A segunda canção do Clube da Esquina (Lado A), logo após "Tudo que você podia ser" é "Cais", uma parceria entre Ronaldo Bastos e Milton Nascimento, interpretada por este último. Em vez de estrada, desta vez aparece o signo do cais, tão fértil de sentidos e tão proficuamente representado na literatura e na canção. $O$ cais, em alguma medida, equivale à estação, espaço de encontros e despedidas, de chegadas e partidas, de términos e recomeços. No entanto, para além desses sentidos, o cais é parte importante da construção do próprio mundo moderno, espaço de migrações e de viagens, tráfego entre pessoas de diferentes origens, raças, nacionalidades e histórias. É, portanto, o eixo fixo que garante a possibilidade de mobilidade, circulação, trânsito e comércio, a entrada e saída de mercadorias e de pessoas. Para o mundo atlântico, o cais e o porto são os pontos de partida dos colonizadores, mas também ponto de chegada de pessoas escravizadas, reinício e reformulação de suas identidades. 

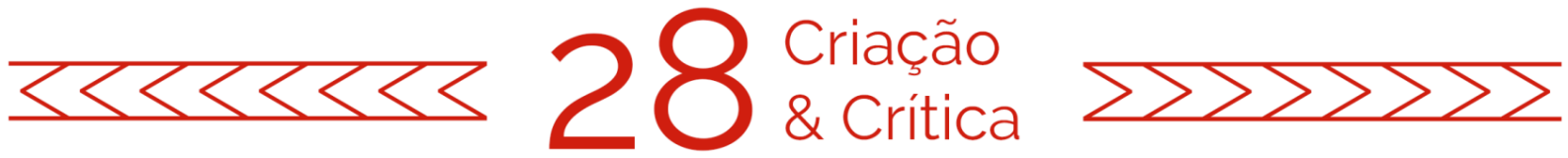

Por outro lado, em metáfora recorrente, o cais funciona como símbolo de chegada; é porto, momento de pacificação, de segurança, de repouso, de término da viagem e dos perigos do mar. Curiosamente, o "Cais" de Milton Nascimento e Ronaldo Bastos aponta justamente para um sentido bem diverso. Diz a letra:

Para quem quer se soltar/ Invento o cais/ Invento mais que a solidão me dá/ Invento lua nova a clarear/ Invento o amor/ E sei a dor / de encontrar/ Eu queria ser feliz/ Invento o mar/ Invento em mim o sonhador

Para quem quer me seguir/ Eu quero mais/ Tenho o caminho do que sempre quis/ E um saveiro pronto pra partir/ Invento o cais/ E sei a vez de me lançar

O hipérbato que inicia a composição já sugere o cais de Milton e Bastos como espaço de mediação entre o aprisionamento (o atraque) e a libertação (a soltura); é para "quem quer se soltar", verso enunciado de modo enfatizar no significante "soltar", bem divididas as sílabas, seu próprio sentido. O mesmo acontece com o paralelo verso "e sei a vez de me lançar", desta vez, pelo prolongamento da vogal e subida do tom que melhor representam sonoramente o gesto do lançamento. A canção se dedica a contar, antes de tudo, um processo demiúrgico: o cais é aqui ponto de partida da criação. Assim, a anáfora do verbo "Invento" vai gerando gradativamente o cais, a lua, o mar, o saveiro pronto para partir.

O canto de Milton Nascimento vai reforçando cada etapa da criação, fazendo pausas, as quais nos dão tempo de assistir à composição do cenário, parte por parte, como numa sequência cinematográfica de quadros, ou mesmo de um mesmo quadro que se amplia. As subidas de tom e o prolongamento das vogais em momentos de maior temperatura passional ("que a solidão me dá", "e sei a dor/ de encontrar"...) enunciam a invenção do amor (e a conseguinte dor do encontro) além de marcarem um enlace de rara beleza entre palavra, canto e melodia.

O próprio sujeito cancional, agente e alvo de sua fabulação, inventa também para si o sonhador, aquele que deseja a felicidade e sabe onde buscá-la. Assim, podemos afirmar que "Cais" é mais uma das muitas canções de Clube da esquina atravessada pelos sentidos da mobilidade (a estrada, o saveiro e o trem), do compromisso existencialista com a autenticidade do ser e de seus desejos ("Tudo que você podia ser", "Nuvem cigana", "Clube da esquina n 2"), e da canção como força de criação de mundos ("Invento o cais").

A imagem do saveiro saindo em noite de lua também pode nos conduzir ao próprio cenário da pesca e, portanto, de novo ao universo do trabalho e do trabalhador. Nesse sentido, a cena acaba atravessada por uma dimensão quase caymmiana, em uma paisagem em tudo construída por meio da projeção que o pescador faz do mar e de sua sabedoria sobre o momento oportuno de se lançar. Vale lembrar também que o disco subsequente de Milton Nascimento é o Milagre dos peixes, o que reforça essa possibilidade de leitura. 

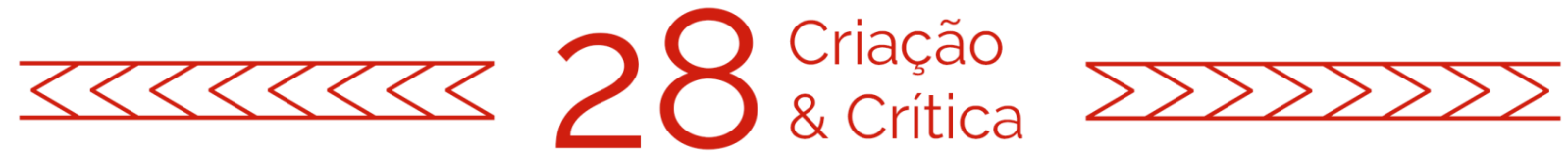

No entanto, outras camadas vêm se sobrepor a essa formulação. De saída, é interessante registrar como a inserção dessa canção em um disco mineiro sugere com certa graça a ausência do porto e, assim, a necessidade de inventá-lo. Mas é na dimensão racial que a voz (e o corpo) de Milton Nascimento emprestam à letra é que se encontram elementos absolutamente instigantes. Nesse sentido, vale pensar esse cais a partir do próprio Brasil e sua formação escravocrata, quando percebemos que o cais é o espaço de chegada da população negra escravizada, em seu movimento de diáspora compulsória pelo mundo atlântico.

Assim, o cais ganha ainda mais uma camada na dualidade entre prisão e soltura, na qual o regime escravocrata responsável pela formação nacional vem se somar à primeira instância de fixidez e estagnação que a própria palavra suscita. Por meio da canção, o sujeito se afirma e se reencontra e, contra o cais real e o mar histórico que trouxe os escravizados pelo Atlântico, inventa ele mesmo um outro cais e um outro mar, e não só se lança por ele, como também leva no saveiro sua voz. Esse cais é, portanto, também espaço de reencontro, de corpos e vozes diaspóricas que, por meio da canção popular, são capazes de se reencontrar e de formular um outro real, que começa na revisão poética dos sentidos que têm o cais, o porto, o saveiro e o mar.

\section{Coração americano}

Como já se disse, o disco Milton (1970) apresenta algumas indicações para compreender a gestação de Clube da Esquina, especialmente pela presença de duas canções, que são "Para Lennon e McCartney" e a primeira versão de "Clube da esquina". Especialmente no primeiro caso, é possível pensar uma relação importante com a questão da latino-americanidade, que é outra temática recorrente na obra de Milton Nascimento.

"Para Lennon e McCartney", canção de Lô Borges, Márcio Borges e Fernando Brant, começa estranhamente pela conjunção "porque" (tal como ocorre em "Clube da esquina $n^{\circ}$ 2") e, assim, pelo hipérbato de uma oração causal: "porque vocês não sabem do lixo ocidental/ não precisa medo não/ não precisa da solidão/ todo dia é dia de viver" (aliás, sentença enfatizada pela voz potente de Milton Nascimento, pedindo atenção da dupla fundamental do pop internacional). $\mathrm{Na}$ estrofe seguinte (e paralela), o sujeito lírico afirma, desta vez, "porque você não verá meu lado ocidental". Assim, esta voz que fala anuncia-se como oriunda de um ponto invisível do ocidente.

Em outra formulação, o que se afirma é que, uma vez que esse "vocês" (Lennon e McCartney e, por extensão, os artistas sob os holofotes do mundo ocidental) não sabem do "lixo ocidental" (no caso, as periferias, tanto no sentido de "Terceiro Mundo", tão em voga naquele momento, mas os próprios grupos humanos antes subalternizados). $\mathrm{Na}$ sequência, afirma-se como o medo, a solidão e a timidez seriam desnecessários mediante o imperativo de viver (deixar ser, deixar estar, para aproveitar a relação com a contemporânea "Let it be"). 

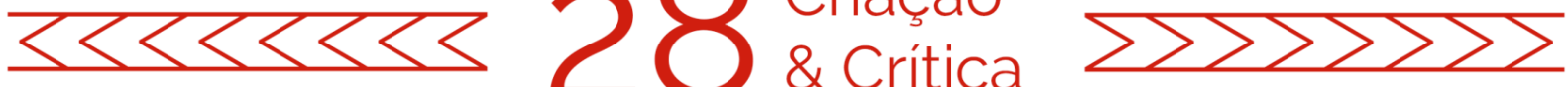

Na terceira e última estrofe, a letra afirma: "Eu sou da América do Sul/ eu sei, vocês não vão saber/ mas agora sou cowboy/ sou do ouro, eu sou vocês/ sou do mundo, sou Minas Gerais". Vale pensar que a canção utiliza uma sonoridade pop, que poderia ser aproximada do "som universal" para falar de uma questão local. No universo temático, a letra que usa o chavão "todo dia é dia de viver" também se apresenta à moda pop.

Por fim, a menção ao cowboy cria um curto-circuito no conjunto da letra, evocando um símbolo icônico da cultura de massas, desta vez, a americana (em alusão ao cinema). Em operação semelhante ao Guimarães Rosa, que faz do jagunço um símbolo regional, nacional e universal a um só tempo, o eu-lírico afirma que agora "é cowboy", e "é do ouro", cruzando o símbolo globalmente legível do cinema ao contexto de formação colonial de Minas Gerais, com seus mineradores, e com seus vaqueiros, jagunços e personagens típicos. O auge da letra se estabelece na máxima rimbaudiana em que "o eu é o outro", e que, portanto, Minas Gerais é o mundo, tal qual o sertão roseano.

Além disso, a afirmação de uma identidade latino-americana, que já aparece esboçada no "Canto latino", em parceria com Ruy Guerra, manifesta-se aqui de modo definitivo o que vai seguir como traço relevante temática e estilisticamente na produção de Milton. A canção para o filme Os deuses e os mortos de Ruy Guerra fala sobre conflitos no sul da Bahia entre grupos de coronéis e diz "a primavera que espero/ por ti irmão e hermano/ só brota em ponta de cano/ em brilho de punhal puro/ brota em guerra e maravilha/ na hora, dia e futuro/ da espera virar...".

Vale lembrar que ao longo dos anos 1970, Milton Nascimento fará várias aproximações com a cultura latina, das quais a gravação de "Volver a los 17", da chilena Violeta Parra, em duo com a argentina Mercedes Sosa - a voz da América - no disco Geraes de 1978 é emblemática. Aliás, anos depois, o artista gravaria um disco inteiro em parceria com a cantora argentina e com o também argentino León Gieco, Corazón Americano, de 1986.

Em Clube da esquina, Milton Nascimento interpreta um bolero, ritmo latinoamericano de relevância inclusive para a história do rádio no Brasil. No entanto, o compositor de "Dos cruces" é o espanhol Carmelo Larrea, que nos anos 1950 ganhou projeção internacional. A bela gravação de Milton não deixa de ser, por isso, uma aproximação com o universo hispano-americano e, não por acaso, a faixa "San Vicente", que trata diretamente da questão da América Latina, está pouco depois.

Essa última canção, parceria de Fernando Brant e Milton Nascimento, interpretada por este, é a terceira do lado B do disco. Convém salientar que o título apresenta um nome católico e registro de língua espanhola, que dá nome a uma cidade imaginária. Esse nome, contudo, parece recorrentemente em topônimos especialmente de municípios espalhados pelos diversos países da América Latina, como Paraguai, Argentina, Chile, Colômbia, Peru, El Salvador, Guatemala e Honduras, além de dar nome a algumas cidades da Espanha. São Vicente dá nome também a uma das capitanias hereditárias do Brasil, exatamente aquela que abrange uma parte da região Sudeste, incluindo parte do Rio de Janeiro, de São Paulo e do sul de Minas Gerais. Essa capitania 

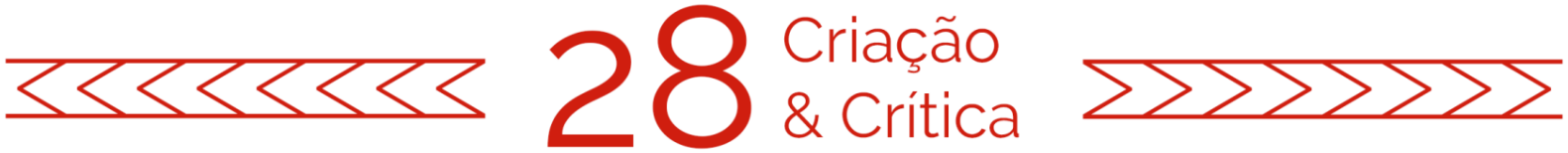

era uma das mais prósperas desse período, e foi também onde se teria formado a primeira vila do Brasil.

Veja-se que a sobreposição dessas informações contribui para um caráter simbólico da "San Vicente" da canção, aproximando os países americanos por sua colonização ibérica e remetendo a um espaço de origem do próprio país - um espaço intimamente associado a um termo hispânico, o que de saída reduz a diferença de idiomas que coloca o Brasil em lugar de destaque em relação ao resto da América Latina.

Além dessa aproximação de origem, que aponta para os traços formativos do sistema colonial nesses países, há de se observar também que a América Latina se torna central na discussão política dos anos 1960, especialmente após a Revolução Cubana de 1959. Como se sabe, a vitória de Fidel Castro e de Che Guevara em território cubano poderia ser apenas a primeira etapa de um projeto mais amplo de tentativa de saída radical à esquerda, como remédio para as mazelas do passado colonial que aproxima as histórias desses países. No entanto, a reação conservadora, apoiada em uma política de alinhamento aos EUA, ajudou a resultar no espalhamento de ditaduras militares (ou civismilitares) por toda a América, especialmente entre o final dos anos 1960 e ao longo de toda a década de 1970, como ocorreu à Argentina, ao Chile e ao próprio Brasil.

Para além das mazelas decorrentes das colonizações na América Latina, guardadas suas especificidades, é inegável que também traços culturais comuns contribuem para outras formas de aproximação entre esses países. A canção popular oferece-se, nesse sentido, como fértil espaço de intercâmbio cultural, desde a época do rádio no Brasil, quando tangos e boleros compunham parte relevante da formação musical. Não por acaso, um bolero abre esse lado do disco, o mesmo que tem "San Vicente".

A letra começa afirmando: "Coração americano/ Acordei de um sonho estranho/ Um gosto, vidro e corte/ Um sabor de chocolate/ No corpo e na cidade/ Um sabor de vida e morte/ Coração americano/ Um sabor de vidro e corte". A entrada da canção, no que se inclui seu instrumental e a forma do canto, nos coloca imediatamente diante de um sentimento de identidade em relação à América. O sintagma "coração americano" compõe um anacoluto, figura sintática que deixa o termo sem função em relação à oração que sucede, embora interfira semanticamente em tudo que se segue.

A narrativa, enfim, começa com o sujeito lírico acordando de um sonho estranho, o que nos instala no campo fronteiriço entre o real e o onírico. Contribui para isso a imagem sinestésica que combina "um gosto, vidro e corte" e "um sabor de chocolate". O vidro e o corte, que apontam logo para a impressão tátil da dor e o universo simbólico da quebra, tornam-se dor. O chocolate surge como contraponto sensorial, agradável em paladar e aroma, além de evocar a América Latina, em sua origem histórica de cultivo na civilização maia, difundindo-se pela América Central e pela América do Sul. Além disso, vale lembrar que o chocolate aqui reverbera o cacau que aparece em "Cravo e canela", reforçando seu intertexto com a Costa do Cacau baiana, aproximando esses dois pontos geográficos latino-americanos pela referência ao ingrediente.

A imagem, um tanto quanto surrealista, apresenta-se paradoxalmente no fio entre a vida e a morte, atravessada pelos signos do cacau, da vida e da morte, que perpassam 

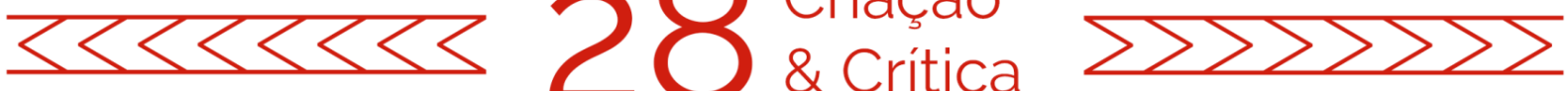

sujeito e cidade. Na estrofe seguinte, surge o título da canção, e também sem apresenta um traço racial - "A espera na fila imensa/ E o corpo negro se esqueceu/ Estava em San Vicente/ A cidade e suas luzes/ Estava em San Vicente/ As mulheres e os homens/ Coração americano/ Um sabor de vidro e corte". A letra tal como o sonho estranho tentando ser domesticado pela racionalidade, vai entregando aos poucos as cenas, coordenadas sintaticamente e reiteradas.

Com algum esforço, conseguimos ir reunindo os cacos da letra: o sujeito em San Vicente, a cidade e suas luzes, homens e mulheres, um sentimento americano, uma ambiguidade de sensações, chocolate, vidro e corte, uma espera em uma fila imensa e "o corpo negro que se esqueceu", versos que na terceira estrofe transmutam-se no paralelismo em "As horas não se contavam/ E o que era negro anoiteceu"). Vê-se como a enigmática "fila imensa" é justamente quem abre a estrofe, contribuindo para a dificuldade de recomposição do sentido íntegro da canção, a não ser se tomada em conjunto, com canções como "Estrelas" ("Poeira, na noite/ a festa da noite/ Guerreira, estrela da morte/ festa negra amor/ mas é tarde") ou "Os povos" ("Eh! Minha cidade/ Aldeia morta, anel de ouro, meu amor/ Na beira da vida/ A gente torna a se encontrar só"). Ainda mais quando pensamos que o lado B do disco, que começa com "Dos cruces" e tem "San Vicente", termina com "Clube da esquina no 2", com a reafirmação do sonho e da importância de tomar as ruas e encher as esquinas.

Nessa cidade mítica e original, resgatada nas trevas do sonho e da memória, a identidade negra e a identidade latino-americana se cruzam em uma cidade atravessada por um passado colonial comum, que persiste em deixar suas marcas no presente. Essas marcas enunciam a força cultural dessas vozes, e de uma longa espera, uma sensação mista de esperança e frustração, a persistência na boca da noite de um gosto de sol. É isso que a canção, tal qual mais uma peça de um filme em quebra-cabeça, nos revela sobre o conjunto do disco.

\section{Um gosto de sol}

Aceitando haver muito mais a se dizer sobre o Clube da esquina, entende-se que a análise das canções feita acima, colabora ao iluminar alguns pontos fundamentais do caráter coletivo e conceitual do disco, evidenciando também o atravessamento do contexto histórico cultural a que pertence e algumas de suas implicações identitárias. O disco, de fato, procede a seu processo de montagem, compondo sua primeira parte, que vai de "Tudo que você podia ser" a "Clube da Esquina n 2", com suas estradas, esquinas e sonhos, e depois de "Paisagem da janela" a "Aos que vão nascer", com suas visões e vaticínios.

Em meio a uma paleta de cores variada e processos vanguardistas e cinematográficos, o disco também conta uma história, a história de vozes de um estado brasileiro do interior, que quer promover franco diálogo entre a cultura do país e do mundo e que, em meio a sobrepostas camadas de opressão, representa incansavelmente a liberdade. Talvez, possamos atribuir o gosto pelos contrastes ao barroco que dá forma a 

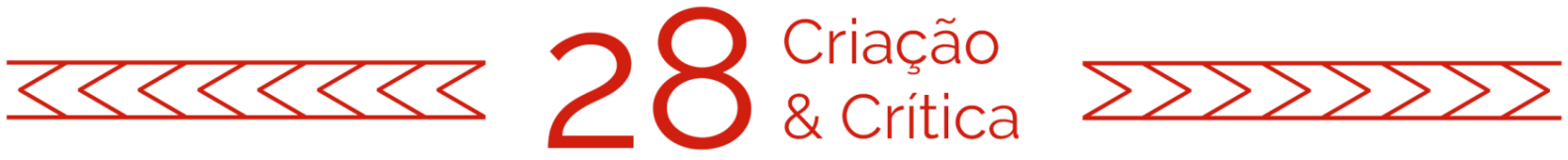

tantas cidades de Minas Gerais. No entanto, chama atenção a imagem "persistindo na boca da noite um gosto de sol", na penúltima canção do disco. Além dela, uma faixa de encerramento, que tem título similar ao célebre poema de Brecht "Aos que vão nascer". Assim diz a canção: "Respostas virão do tempo/ um rosto claro e sereno me diz/ e eu caminho com pedras na mão".

\section{Referências bibliográficas}

AMADO, Jorge. Gabriela, cravo e canela: crônica de uma cidade do interior. São Paulo: Companhia das Letras, 2012.

BRECHT, Bertold. Poemas 1913-1956. Tradução de Paulo César de Souza. São Paulo: Editora 34, 2000.

BORGES, Márcio. Os sonhos não envelhecem: Histórias do clube da esquina. São Paulo: Geração Editorial, 2019.

CAMPOS, Augusto de. Balanço da bossa e outras bossas. São Paulo: Perspectiva, 1993.

COELHO, Frederico. Eu brasileiro confesso minha culpa meu degredo - cultura marginal no Brasil das décadas de 1960 e 1970. Rio de Janeiro: Civilização Brasileira, 2010.

COHN, Sérgio. Nuvem cigana - poesia e delírio no Rio dos anos 70. (COHN, Sergio (org.). Rio de Janeiro: Azougue, 2007.

GILROY, Paul. O Atlântico negro: modernidade e dupla consciência. São Paulo: Ed. 34; Rio de Janeiro: Universidade Candido Mendes, Centro de Estudos Afro-Asiáticos, 2001. GULLAR, Ferreira. A luta corporal. São Paulo: Companhia das Letras, 2017.

HALL, Stuart. Da diáspora: identidades e mediações culturais. Belo Horizonte: Editora UFMG, 2013.

HOLLANDA, Heloísa Buarque de. Impressões de viagem. São Paulo: Brasiliense, 1980. . \& GONÇALVES, Marcos A. Cultura e participação nos anos 60. São Paulo: Brasiliense, 1987.

PEREIRA, Carlos Alberto M. Retrato de época: poesia marginal anos 70. Rio de Janeiro: FUNARTE, 1981.

ROSZAK, Theodore. A contracultura. Trad. Donaldson M. Garschagen. Petrópolis: Vozes, 1972.

SUKMAN, Hugo. Histórias paralelas - 50 anos de música brasileira. Rio de Janeiro: casa da palavra, 2011.

TATIT, Luiz. A canção - eficácia e encanto. São Paulo: Atual, 1986.

. O cancionista: composição de canções no Brasil. São Paulo: Edusp, 2002. . O século da canção. São Paulo: Ateliê, 2004.

VELOSO, Caetano. O mundo não é chato. [organização e apresentação Eucanaã Ferraz] - São Paulo, Companhia das Letras, 2005. . Verdade tropical. São Paulo: Companhia das Letras, 1997. 


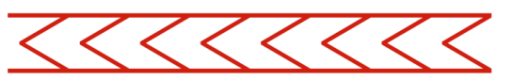

28 criagio

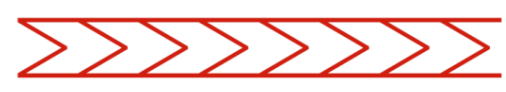

TELES, Gilberto Mendonça. Vanguarda europeia \& Modernismo brasileiro. Petrópolis, Rio de Janeiro: Vozes, 2009.

Recebido em: 25/07/2020 Aceito em: 08/10/2020

Referência eletrônica: JULIÃO, Rafael. Encontros, imagens e cruzamentos no álbum Clube da Esquina (1972). Criação \& Crítica, n. 28, p., dez. 2020. Disponível em: $<$ http://revistas.usp.br/criacaoecritica>. Acesso em: dd mmm. aaaa. 